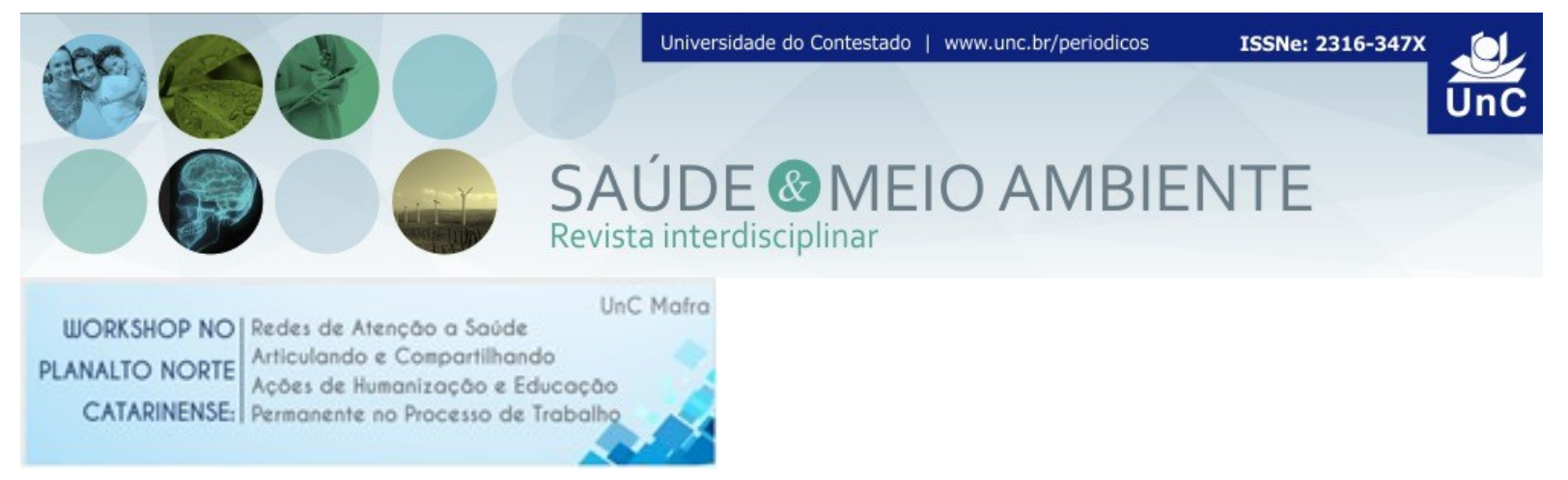

\title{
A HORA DA HISTÓRIA: OFICINA DE CONTAÇÃO DE HISTÓRIAS PARA TRABALHAR TEMAS EM SAÚDE COM CRIANÇAS
}

Franceli Groskopf ${ }^{1}$

\section{RESUMO}

INTRODUÇÃO: Trabalhar promoção da saúde explorando o universo infantil exige uma metodologia apropriada e criativa. O projeto "A Hora da História" é desenvolvido no município de Itaiópolis, Santa Catarina, com crianças de dois a seis anos de idade e consiste em contar histórias e a partir delas trabalhar temas em saúde e valores morais. A arte de contar histórias é utilizada desde muito antigamente pelos povos como meio de transmitir seus conhecimentos, mitos e rituais, disseminando seus costumes e sua cultura (SOUZA; BERNARDINO, 2011). Para trabalhar temas em saúde com crianças, as histórias servem de instrumento para acessá-las de forma lúdica e descontraída. Dentro das possibilidades da promoção da saúde, percebe-se diversas ações voltadas para gestantes, pessoas com doenças crônicas, adolescentes e adultos de uma forma geral. Entretanto, ações direcionadas à saúde do público infantil, principalmente na primeira infância (de zero a cinco anos), encontram-se muito relacionadas aos cuidados que os pais e adultos devem ter com a saúde das crianças, como por exemplo, o incentivo a amamentação e a vacinação. Este projeto desenvolve-se diretamente com as crianças, sendo um meio de interação que favorece a discussão e a conscientização das crianças sobre temas relacionados à saúde e valores morais. OBJETIVOS: Abordar assuntos relacionados à saúde e valores morais com crianças, além de estimular aspectos cognitivos, emocionais e sociais que auxiliem no desenvolvimento da criança. RELATO DE EXPERIÊNCIA: O projeto teve início em setembro de 2017. Trata-se de uma atividade desenvolvida em parceria com quatro creches municipais, onde uma profissional da Prefeitura Municipal de Itaiópolis que atua na promoção da saúde desloca-se até as creches para fazer a contação. Inicialmente é realizado um momento de apresentações e dinâmicas para despertar a curiosidade das crianças. Em seguida é contada uma história utilizando recursos visuais e auditivos como fantasias, maquiagens, acessórios, instrumentos musicais, ilustrações e fantoches. As histórias podem ser contos de fadas, lendas, fábulas, contos populares, histórias retiradas da internet ou de livros, sempre adequadas à idade do público-alvo. Após a história é realizado um momento de interação com as crianças, com perguntas e reflexões sobre a história. Entre os temas trabalhados pode-se citar alimentação

\footnotetext{
${ }^{1}$ Terapeuta Ocupacional. Mestre em Saúde Coletiva (FURB - Universidade Regional de Blumenau). Especialista em Saúde Mental e Atenção Psicossocial (Escola de Saúde Pública de Santa Catarina professor Mestre Oswaldo de Oliveira Maciel). Santa Catarina. Brasil. E-mail: frangroskopf@gmail.com
}

Saúde Meio Ambient. v. 6, n. esp. (Anais Workshop), p. 4-5, dez. 2017

ISSN 2316-347X 
saudável, hábitos de higiene, como tomar banho e escovar os dentes e valores morais como respeito, cooperação, responsabilidade, honestidade, justiça, entre outros. São atendidas aproximadamente oitenta crianças semanalmente, dividas em turmas nas creches. RESULTADOS: Percebe-se que as crianças interagem entre si, com os personagens e com a contadora no momento da história. Respondem às perguntas e compreendem o sentido da história, relatando experiências pessoais relacionadas ao tema trabalhado. As professoras também relatam que após as histórias as crianças continuam lembrando e discutindo, fazendo comparações e associando os temas ao seu dia-a-dia. CONCLUSÕES: O desenvolvimento infantil é um processo constante que acontece por meio das interações e aprendizagens da criança. O projeto "A Hora da História" contribui nesse processo, sendo um meio de abordar temas em saúde com uma linguagem e metodologia adequadas ao universo infantil.

Palavras-Chave: Contação de histórias. Crianças. Promoção da Saúde.

\section{REFERÊNCIAS}

SOUZA, L. O.; BERNARDINO, A. D. Educere et Educare. Revista de Educação. v. 6, n. 12, p. 235-249, jul./dez., 2011. Disponível em: <http://e-revista.unioeste.br/ index.php/educereeteducare/article/view/4643/489>. Acesso em 05 nov. 2017.

Resumo recebido em: 11/12/2017

Resumo aprovado em: 17/12/2017

Resumo publicado em: 20/12/2017 